\title{
Mechanism-based genotoxicity screening of metal oxide nanoparticles using the ToxTracker panel of reporter cell lines
}

Hanna L Karlsson ${ }^{*}$, Anda R Gliga ${ }^{1}$, Fabienne MGR Calléja², Cátia SAG Gonçalves², Inger Odnevall Wallinder ${ }^{3}$, Harry Vrieling ${ }^{2}$, Bengt Fadeel ${ }^{1}$ and Giel Hendriks ${ }^{2^{*}}$

\begin{abstract}
Background: The rapid expansion of manufacturing and use of nano-sized materials fuels the demand for fast and reliable assays to identify their potential hazardous properties and underlying mechanisms. The ToxTracker assay is a recently developed mechanism-based reporter assay based on mouse embryonic stem (mES) cells that uses GFP-tagged biomarkers for detection of DNA damage, oxidative stress and general cellular stress upon exposure. Here, we evaluated the ability of the ToxTracker assay to identify the hazardous properties and underlying mechanisms of a panel of metal oxide- and silver nanoparticles (NPs) as well as additional non-metallic materials (diesel, carbon nanotubes and quartz).
\end{abstract}

Methods: The metal oxide- and silver nanoparticles were characterized in terms of agglomeration and ion release in cell medium (using photon cross correlation spectroscopy and inductively coupled plasma with optical emission spectroscopy, respectively) as well as acellular ROS production (DCFH-DA assay). Cellular uptake was investigated by means of transmission electron microscopy. GFP reporter induction and cytotoxicity of the NPs was simultaneously determined using flow cytometry, and genotoxicity was further tested using conventional assays (comet assay, $Y-\mathrm{H}_{2} \mathrm{AX}$ and RAD51 foci formation).

Results: We show that the reporter cells were able to take up nanoparticles and, furthermore, that exposure to $\mathrm{CuO}, \mathrm{NiO}$ and $\mathrm{ZnO}$ nanoparticles as well as to quartz resulted in activation of the oxidative stress reporter, although only at high cytotoxicity for ZnO. NiO NPs activated additionally a p53-associated cellular stress response, indicating additional reactive properties. Conventional assays for genotoxicity assessment confirmed the response observed in the ToxTracker assay. We show for CuO NPs that the induction of oxidative stress is likely the consequence of released $\mathrm{Cu}$ ions whereas the effect by $\mathrm{NiO}$ was related to the particles per se. The DNA replication stress-induced reporter, which is most strongly associated with carcinogenicity, was not activated by any of the tested nanoparticles.

Conclusions: We conclude that the ToxTracker reporter system can be used as a rapid mechanism-based tool for the identification of hazardous properties of metal oxide NPs. Furthermore, genotoxicity of metal oxide NPs seems to occur mainly via oxidative stress rather than direct DNA binding with subsequent replication stress.

Keywords: Metal oxide nanoparticles, Nanomaterials, ToxTracker, High-throughput screening, Genotoxicity, Oxidative stress, Reporter cells

\footnotetext{
* Correspondence: Hanna.L.Karlsson@ki.se; g.hendriks@lumc.nl

'Nanosafety \& Nanomedicine Laboratory, Division of Molecular Toxicology,

Institute of Environmental Medicine, Karolinska Institutet, Stockholm, Sweden

${ }^{2}$ Department of Toxicogenetics, Leiden University Medical Center, Leiden,

the Netherlands

Full list of author information is available at the end of the article
}

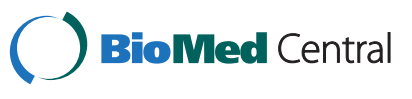

(c) 2014 Karlsson et al.; licensee BioMed Central Ltd. This is an Open Access article distributed under the terms of the Creative Commons Attribution License (http://creativecommons.org/licenses/by/4.0), which permits unrestricted use, distribution, and reproduction in any medium, provided the original work is properly credited. The Creative Commons Public Domain Dedication waiver (http://creativecommons.org/publicdomain/zero/1.0/) applies to the data made available in this article, unless otherwise stated. 


\section{Background}

The exponential increase in the total number of engineered nanoparticles (NPs) for research, development, and commercialization requires tools for rapid and efficient toxicity screening [1]. Ultimately, such rapid screening should allow for mechanistic profiling in order to better inform on hazard identification and to improve risk assessment [2]. Oxidative stress has been identified as a major mechanism of toxicity for nanoparticles. The socalled oxidative stress paradigm describes how increased levels of reactive oxygen species (ROS) lead to various cellular responses, such as antioxidant response, inflammation and cytotoxicity, following nanoparticle-cell interactions [3]. ROS and inflammation can for instance be a consequence of the released toxic metal ions or a reactive particle surface leading to lysosomal destabilization $[4,5]$. One main concern following exposure to inhalable particles is their potential genotoxicity, which is closely associated with carcinogenesis. The mechanisms of NP genotoxicity are still not well understood but oxidative stress and/or direct interactions with DNA are considered important [6,7]. Direct DNA interaction could represent a more nano-specific mechanism due to the fact that small nanoparticles may reach the nucleus via transportation through the nuclear pore complexes [8]. However, also larger nanoparticles of e.g. silver $(60 \mathrm{~nm})$ [9], $\mathrm{SiO}_{2}(40-70 \mathrm{~nm})$ [10] and $\mathrm{CuO}$ $(50-100 \mathrm{~nm})$ [11] have been observed in the nucleus suggesting that larger NPs may get access to the DNA in dividing cells when the nuclear membrane disassembles.

The most commonly used methods for assessing genotoxicity of nanomaterials up to date are the comet assay and the micronucleus $(\mathrm{MN})$ tests $[6,12]$. However, such assays are time consuming and give limited information on the mechanisms of damage, thereby hampering human hazard assessment. An alternative approach for rapid genotoxicity testing could be reporter cell systems in which the induction of certain genes can be studied by a simple readout such as luminescence or fluorescence. These reporter assays indicate the cellular signaling pathways that are activated upon exposure, thereby providing insight into the mechanisms of toxicity. However, only very few examples of studies using reporter cell lines for assessing toxicity of NPs have been reported [13]. The mammalian GreenScreen HC assay that uses a Gadd45 $\alpha$ GFP (green fluorescent protein) reporter gene in TK6 human lymphoma cells [14] has been extensively validated for genotoxicity testing of chemicals. Gadd $45 \alpha$ is directly controlled by the tumor suppressor p53 but also by various additional cellular stress-related signaling pathways, thereby limiting the usability of the GreenScreen $\mathrm{HC}$ assay for identification of the primary mechanism of toxicity of compounds [15].

Recently, we developed an in vitro assay called ToxTracker that can rapidly provide mechanistic insight into the biological damage induced by chemicals [16]. The ToxTracker assay consists of a panel of mouse embryonic stem $(\mathrm{mES})$ cell lines that each contains a different GFP-tagged reporter for a distinct cellular signaling pathway. The preferential induction of the different reporters indicates the nature of biological damage and associated cellular response pathways. The ToxTracker assay can discriminate between the induction of DNA damage via direct DNA interaction, oxidative stress and general cellular stress (Figure 1A). The DNA damage-associated Bscl2GFP reporter depends on the ATR (ataxia telangiectasia mutated and Rad3-related)-associated DNA damage signaling pathway and is selectively activated after exposure to genotoxic agents and the subsequent interference with DNA replication [16]. The Srxn1-GFP reporter is preferentially induced upon oxidative stress and is part of the Nrf2 (Nuclear Factor, Erythroid Derived 2, Like 2) antioxidant response pathway. Finally, the Btg2-GFP reporter gene is controlled by p53 and is activated by various types of cellular stress. The combination of different fluorescent reporter cell lines in a single toxicity assay allows not only for rapid and reliable identification of genotoxic properties of chemicals but also enables mechanistic understanding of different modes of toxicity [16].

Here we investigated whether the ToxTracker assay could be used as a rapid mechanism-based tool for assessing genotoxic effects of NPs. In addition, we explored particle $v s$. ion effects in order to identify the particle properties that determine the reporter cell response. For this purpose we used a panel of well-characterized nanomaterials including metal oxide NPs $(\mathrm{CuO}, \mathrm{ZnO}, \mathrm{NiO}$, $\mathrm{CeO}_{2}, \mathrm{Fe}_{3} \mathrm{O}_{4}, \mathrm{TiO}_{2}$ ) with a primary particle size $<100 \mathrm{~nm}$ and Ag NPs of two specific sizes (10 nm and $40 \mathrm{~nm})$. Additionally, the quartz material DQ12 was included as a poorly soluble benchmark particle, and the results were compared with diesel particles (standard reference material SRM1650b) and multi-walled carbon nanotubes (MWCNTs). The selection of metal oxide NPs was based on their various abilities to cause DNA damage and oxidative stress upon exposure of lung epithelial cells $[17,18]$. Results from the ToxTracker reporter assay were compared with conventional assays for genotoxicity assessment (comet assay, $\gamma-\mathrm{H}_{2} \mathrm{AX}$ and RAD51 foci formation) and NP uptake was confirmed by transmission electron microscopy (TEM).

\section{Results}

Characterization of particle solubility, agglomeration and reactivity

Metal oxide NPs $\left(\mathrm{CuO}, \mathrm{ZnO}, \mathrm{NiO}, \mathrm{CeO}_{2}, \mathrm{Fe}_{3} \mathrm{O}_{4}, \mathrm{TiO}_{2}\right)$ and silver NPs of different sizes $(10 \mathrm{~nm}$ and $40 \mathrm{~nm}$, citrate coated) were carefully characterized in terms of primary size, zeta potential, metal ion release in cell medium, and acellular ROS generation (Table 1). All tested NPs 
A

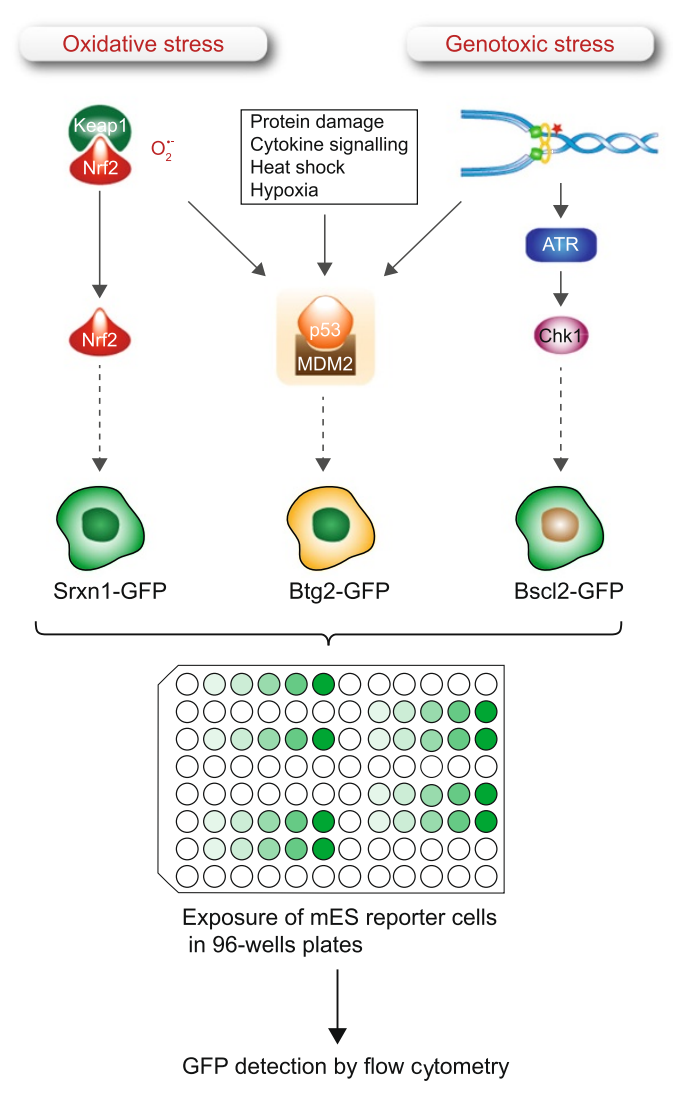

B
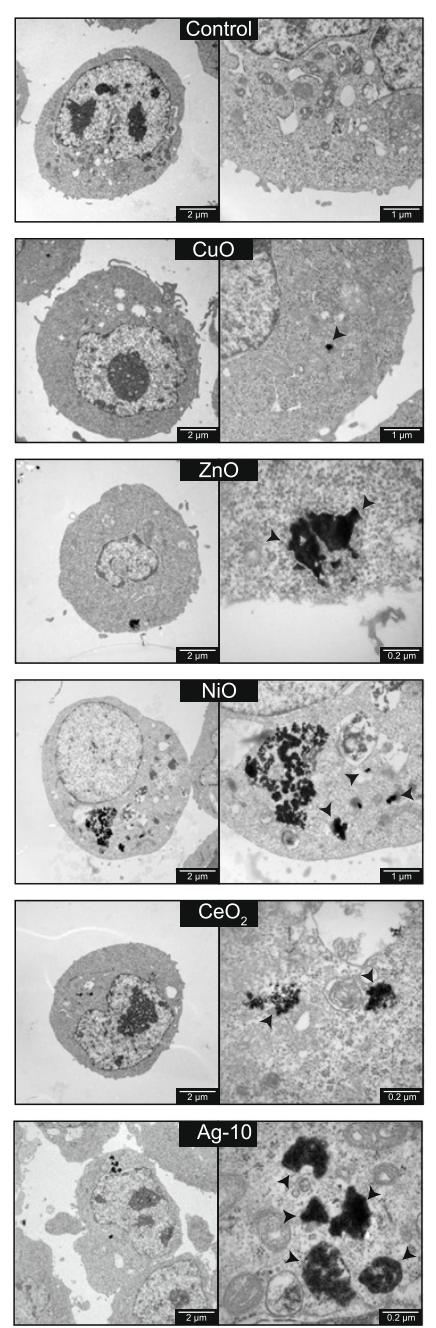

Figure 1 The ToxTracker reporter assay for mechanism-based toxicity testing. (A) The ToxTracker assay consists of a panel of GFP-based $\mathrm{mES}$ cell lines. The GFP reporters indicate activation of the Nrf2-associated antioxidant response, ATR-associated DNA damage response and the p53 cellular stress response. Induction of the GFP reporters as well as cytotoxicity is determined by flow cytometry. (B) Cellular uptake but no evidence for nuclear localization of metal oxide NPs in mES cells. Internalization of the NPs after 24 h exposure to $20 \mu \mathrm{g} / \mathrm{mL} \mathrm{CuO,} \mathrm{30} \mathrm{\mu g/mL} \mathrm{ZnO,}$ $100 \mu \mathrm{g} / \mathrm{mL} \mathrm{NiO}, 100 \mu \mathrm{g} / \mathrm{mL} \mathrm{CeO} 2$ and $10 \mu \mathrm{g} / \mathrm{mL}$ Ag-10 NPs was determined by means of TEM. NPs were taken up by mES cells and were localized in endosomal vesicles or free in the cytoplasm (black arrow heads).

agglomerated to various extents in mES cell culture medium with bimodal and trimodal distributions, but all suspensions contained particles sized $<100 \mathrm{~nm}$ (see Table 1 and Additional file 1: Figure S1). As expected, the NPs showed a high variation in their ability to dissolve/release metal ions in the cell medium. ZnO NPs dissolved rapidly with approximately $40 \%$ reduction in total particle mass already after sonication and centrifugation $(0 \mathrm{~h})$, also indicated by a rapid reduction in particle size and scattered light intensity (kcps) as observed using PCCS measurements (data not shown). Only $20 \%$ of the particle mass remained in solution after $24 \mathrm{~h}$ of exposure (see Table 1 ). $\mathrm{CuO}$ NPs also dissolved to a relatively large extent with time, although significantly slower (2.5\% of the total particle mass after $0 \mathrm{~h}$ and $37 \%$ after $24 \mathrm{~h}$ ). Similar kinetics were evident for the Ag NPs that showed a clear sizedependent metal release with approximately 22\% (Ag-10) and $11 \%$ (Ag-40) of the particle mass dissolved after $24 \mathrm{~h}$. The amount of dissolved metals in solution after $24 \mathrm{~h}$ was significantly lower for $\mathrm{NiO}$ ( $5 \%$ after $24 \mathrm{~h}$ ), and even lower for $\mathrm{TiO}_{2}(<0.1 \%), \mathrm{Fe}_{3} \mathrm{O}_{4}$ and $\mathrm{CeO}_{2}(<<0.01 \%)$. NiO NPs were by far the most efficient particles to generate ROS acellularly, followed by $\mathrm{CuO}$ (though to a significantly lower extent) whereas the other NPs showed no or only a slight increase in ROS production.

\section{Cellular uptake, but no evidence for nuclear localization of metal oxide NPs}

In order to investigate the general applicability of the recently developed mES cell-based ToxTracker assay for 
Table 1 Physico-chemical characterization of the metal and metal oxide nanoparticles

\begin{tabular}{|c|c|c|c|c|c|c|}
\hline \multirow[t]{2}{*}{ Particle } & \multirow[t]{2}{*}{ Size $^{a}(n m, T E M)$} & \multirow{2}{*}{$\begin{array}{l}\text { Size cell medium } \\
\text { (approximate peak } \\
\text { max, nm PCCS) }\end{array}$} & \multirow[t]{2}{*}{ Zeta potential, mV } & \multicolumn{2}{|c|}{ Dissolved amount of metals in cell medium, wt $\%$} & \multirow[t]{2}{*}{ Acellular ROS ${ }^{b}$} \\
\hline & & & & $\mathrm{Oh}$ & $24 \mathrm{~h}$ & \\
\hline $\mathrm{CuO}$ & $20-40$ & 3 and 500 & +31 & 2.5 & 37.2 & 2.3 \\
\hline $\mathrm{Fe}_{3} \mathrm{O}_{4}$ & $20-40$ & 2, 40 and 800 & +2 & $<0.01$ & $<0.01$ & 1.5 \\
\hline $\mathrm{ZnO}$ & $20-200$ & 20,500 and 800 & +27 & 41.3 & 78.5 & 1.1 \\
\hline $\mathrm{TiO}_{2}$ & $20-100$ & 8 and 400 & +6 & 0.1 & 0.1 & 1.3 \\
\hline $\mathrm{NiO}$ & $2-70$ & 20 and 500 & +30 & 0.9 & 5.1 & $>10$ \\
\hline $\mathrm{CeO}_{2}$ & $4-30$ & 8 and 80 & +4 & $<0.01$ & $<0.01$ & 1.3 \\
\hline $\mathrm{Ag} 10$ & 10 & 6, 40 and 200 & N/A & 3.0 & 21.6 & 0.97 \\
\hline $\operatorname{Ag} 40$ & 40 & $10-40$ and 200 & -41.5 & 0.2 & 10.6 & 0.93 \\
\hline
\end{tabular}

${ }^{a}$ Size, estimated from TEM images, and zeta potential (in MilliQ water with $1 \mathrm{mM} \mathrm{NaCl}$ ) were analyzed in previous studies (Karlsson et al., 2008 [17], Kain et al., 2012 [18]), Ag NPs were received from Nanocomposix and were carefully characterized in Gliga et al., 2014 [31].

${ }^{\mathrm{b}}$ Acellular ROS: Times increase compared to control in ROS kinetics (mean slope per $\mathrm{min}$ ), $10 \mu \mathrm{g} / \mathrm{mL}$ particle dispersions.

nanoparticle toxicity testing (Figure $1 \mathrm{~A})$, we first investigated the ability of the mES cells to internalize NPs by means of TEM and by analyzing the side scatter shift by using flow cytometry. Indeed, NPs may cause genotoxic effects via indirect mechanisms [19], but without cellular uptake the applicability of the assay for NP testing will be limited as in the case for the Ames mutagenicity test [20]. Clearly, all the tested metal and metal oxide NPs analyzed using TEM were internalized by the mES cells, but no nuclear localization was observed (Figure 1B). A significant side scatter shift was also observed for all particles in the study (Additional file 1: Figure S2). Although contributions by possible particles tightly bound to the outer cell membrane cannot be excluded, this data support the uptake observed in the TEM analysis. Fewer internalized particles were observed after exposure to $\mathrm{ZnO}$ and $\mathrm{CuO}$ NPs due to their extra- and intracellular dissolution. To further confirm uptake of $\mathrm{CuO}$ NPs we quantified the metal content after exposure of $\mathrm{mES}$ cells to $20 \mu \mathrm{g} / \mathrm{mL}$ for $4 \mathrm{~h}$ by means of atomic absorption spectroscopy (AAS). The results showed a metal content of approx. $6.1 \mathrm{pg} / \mathrm{cell}$ which is in the same range as our previous studies on $\mathrm{CuO}$ NPs uptake in A549 and BEAS-2B cells [21].

\section{The ToxTracker assay identifies distinct toxicity responses} to NPs

Next, we exposed the ToxTracker cell lines to the eight different metal-based NPs for $24 \mathrm{~h}$ and recorded induction of the GFP reporters for DNA damage, oxidative stress and global cellular stress together with cell viability using a 96-well plate-based flow cytometer. Based on previous validation of the ToxTracker assay, a 1.5-fold induction of GFP expression was considered as cut-off for a positive test score [16]. A clear induction of the oxidative stress reporter (Srxn1-GFP) was observed for the $\mathrm{CuO}$ and $\mathrm{NiO}$ NPs (Figure 2A). Importantly, GFP reporter induction is exclusively determined in the intact, viable cells. Stem cells are generally very sensitive to cellular damage and in response rapidly activate their cellular signaling pathways and apoptotic programs. These properties make stem cells a highly sensitive system for detection of the primary toxic properties of chemicals and nanomaterials. The induction was observed for doses at which at least $40 \%$ of the cells were still viable and started from $10 \mu \mathrm{g} / \mathrm{mL}$ for the $\mathrm{CuO}$ and $25 \mu \mathrm{g} / \mathrm{mL}$ for the NiO NPs. The ZnO NPs showed induction of the oxidative stress reporter at concentrations from 20-30 $\mu \mathrm{g} / \mathrm{mL}$, but high levels of cytotoxicity $(>75 \%)$ at these concentrations make the ToxTracker results inconclusive. None of the particles induced the DNA replication stress reporter (Bscl2-GFP), indicating that none of the tested NPs induced significant levels of replication-blocking DNA lesions. In addition to the oxidative stress reporter, the NiO NPs also induced the p53-dependent Btg2-GFP reporter, suggesting that the $\mathrm{NiO}$ NPs induced other types of biological damage to the cells. Exposure of the ToxTracker cells to $\mathrm{CeO}_{2}, \mathrm{Fe}_{3} \mathrm{O}_{4}$, $\mathrm{TiO}_{2}$ and $\mathrm{Ag}$ NPs did not result in any reporter activation (Figure 2A) nor induced any significant cytotoxicity at investigated doses (Figure 2B). The cell viability results based on flow cytometry were confirmed using the Alamar Blue cell viability assay (Additional file 1: Figure S4).

\section{Conventional DNA damage assays confirm the ToxTracker response to NPs}

In order to confirm the ToxTracker responses we tested the NPs in conventional DNA damage assays. First, we performed alkaline as well as FPG (Formamidopyrimidine DNA glycosylase) comet assay following mES cell exposure to the NPs at $20 \mu \mathrm{g} / \mathrm{mL}$ for $4 \mathrm{~h}$ (non-cytotoxic conditions). The alkaline comet assay is able to detect a wide range of DNA damage including strand breaks and alkaline labile sites (ALSs) whereas the FPG comet assay mainly detects oxidized purines [12]. Exposure to $\mathrm{CuO}$ and NiO NPs, as well as $\mathrm{TiO}_{2}$ NPs, gave significant tailing in the alkaline version of the comet assay (Figure 3A). 


\section{- Bscl2-GFP $\quad$ Srxn1-GFP $\triangle$ Btg2-GFP}

A

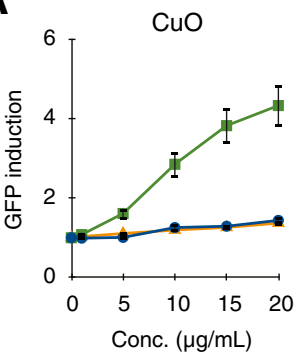

$\mathrm{ZnO}$
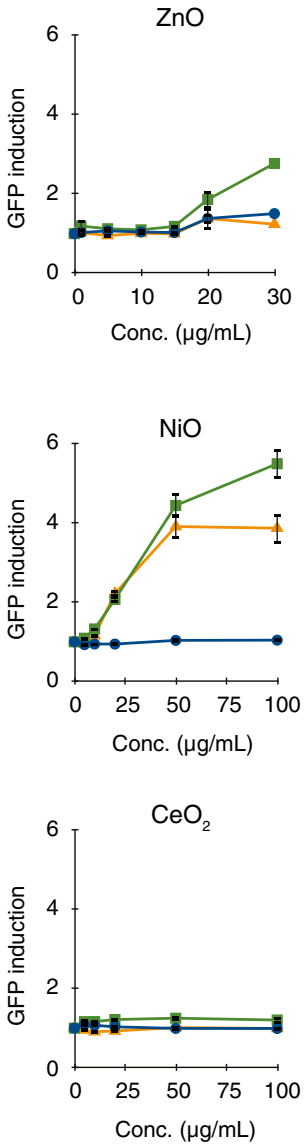

CisPt

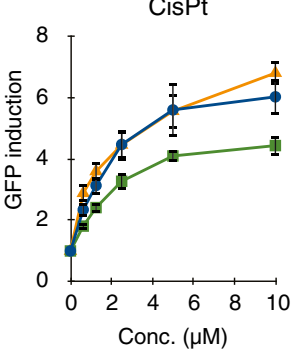

$\mathrm{Fe}_{3} \mathrm{O}_{4}$

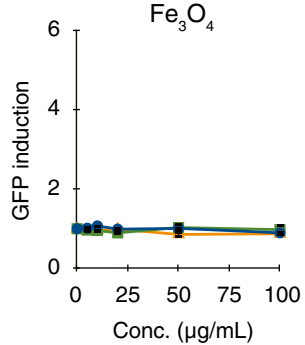

$\mathrm{TiO}_{2}$

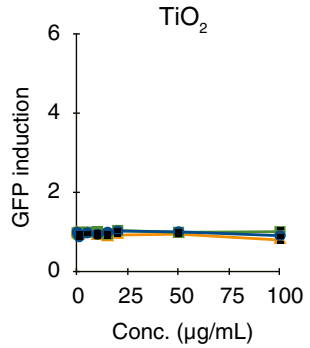

$\mathrm{Ag}-10$
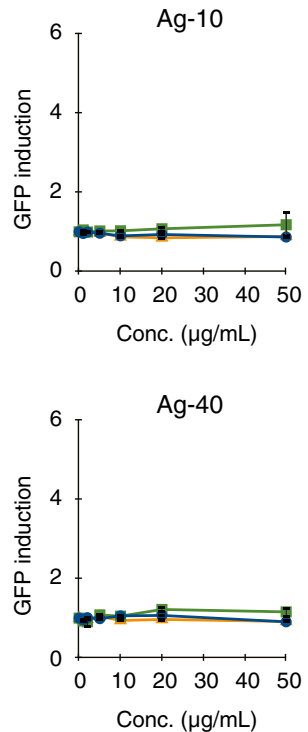

DEM

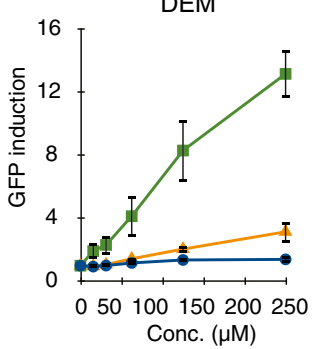

B
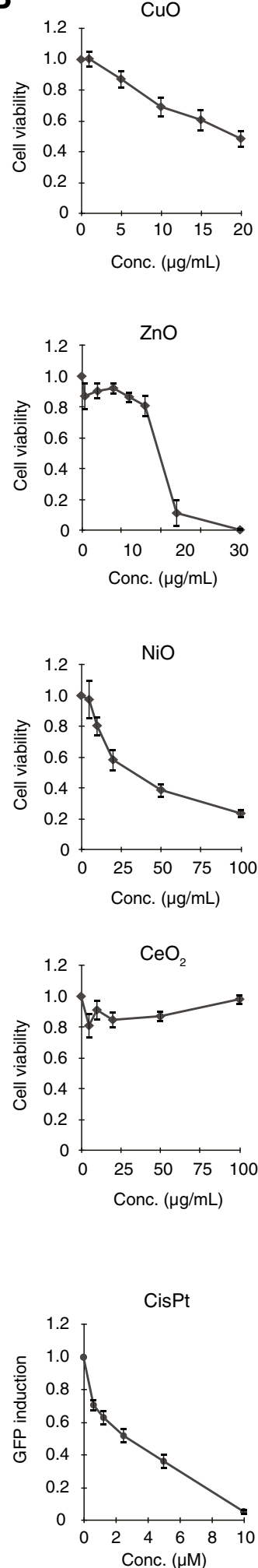
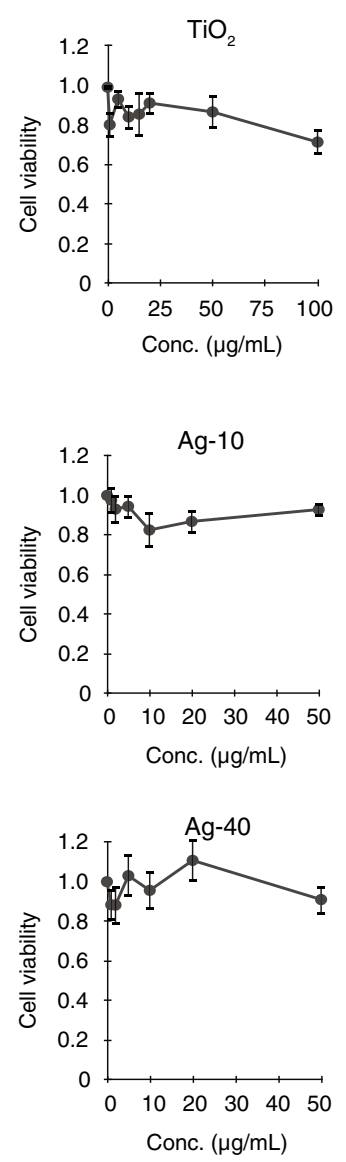

Conc. $(\mu \mathrm{g} / \mathrm{mL})$
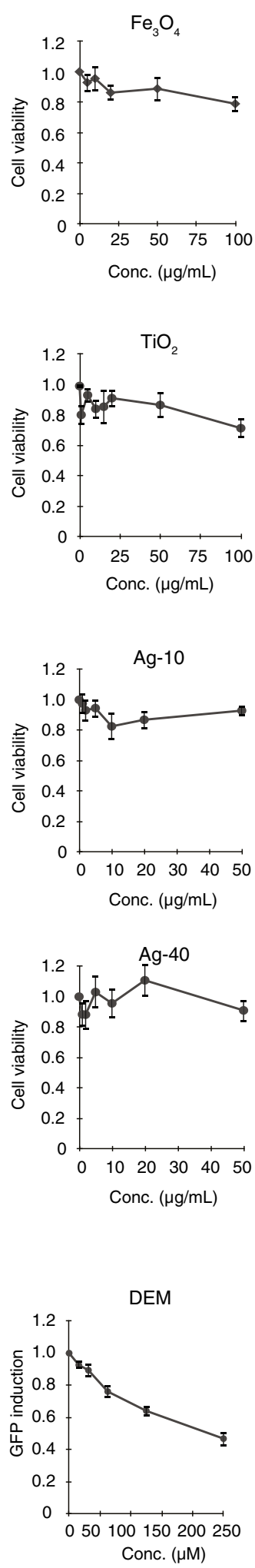

Figure 2 (See legend on next page.) 
(See figure on previous page.)

Figure 2 The ToxTracker assay can identify genotoxic properties of NPs. (A) The ToxTracker reporter cell lines Bscl2-GFP for DNA replication stress, Srxn1-GFP for oxidative stress and Btg2-GFP for p53-associated cellular stress were used to provide mechanistic insight into the biological damage that is induced by various metal-based NPs. Induction of the GFP reporters was determined by flow cytometry after $24 \mathrm{~h}$ exposure. The data show the mean of four independent experiments \pm standard deviation of the mean. (B) Cytotoxicity of the tested NPs was determined by measuring the fraction of intact cells after $24 \mathrm{~h}$ exposure using flow cytometry.

The other NPs did not induce detectable DNA damage at these non-cytotoxic conditions. Furthermore, only $\mathrm{CuO}$ NPs caused an 5-fold induction of FPG sensitive sites, suggesting that oxidative stress is a main mechanism for $\mathrm{CuO}$ toxicity (Figure $3 \mathrm{~B}$ ). The $\mathrm{ZnO}$ also induced tailing in the alkaline comet assay at higher concentrations (Additional file 1: Figure S5). Additional analyses using the neutral comet assay, which is more indicative for double strand DNA breaks, showed no induction by $\mathrm{CuO}$ or $\mathrm{NiO}$ and only slight induction by $\mathrm{ZnO}$ (Additional file 1 : Figure S5). The metal oxide NPs that showed a positive response in the ToxTracker were further investigated for their ability to induce $\gamma \mathrm{H}_{2} \mathrm{AX}$ and RAD51 foci. The histone variant $\mathrm{H}_{2} \mathrm{AX}$ is rapidly phosphorylated at dsDNA breaks (DSB) but also at sites of chromatin relaxation and
ssDNA breaks in mES cells [22]. RAD51 is a protein recruited to DSBs and plays an essential role in repair of DSBs by homologous recombination [23]. Exposure of mES cells to $\mathrm{CuO}, \mathrm{ZnO}$ and $\mathrm{NiO}$ led to an increase in $\mathrm{H}_{2} \mathrm{AX}$ phosphorylation, although the levels were low compared with the control exposure to 10 Gy ionizing radiation (IR) (Figure 3C). In contrast, no RAD51 foci formation was observed after exposure to these NPs. Taken together, these results indicate that $\mathrm{CuO}$ induce ssDNA breaks and oxidative DNA lesions and thus confirms oxidative stress as a main mechanism as identified by the ToxTracker. $\mathrm{NiO}$ predominantly induce ssDNA breaks at non-cytotoxic conditions and possibly act via additional mechanisms that lead to p53 induction, as shown by ToxTracker. Clearly, the particles were not potent in inducing
A

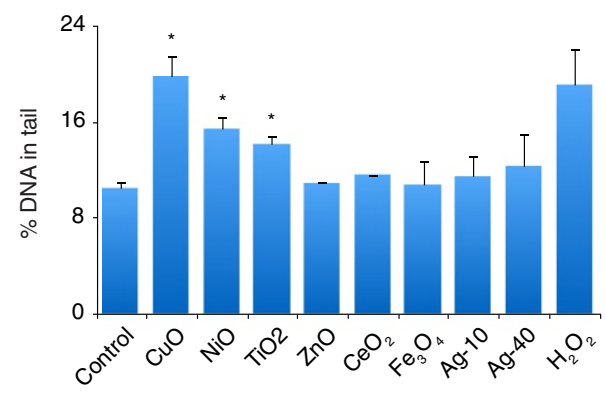

B

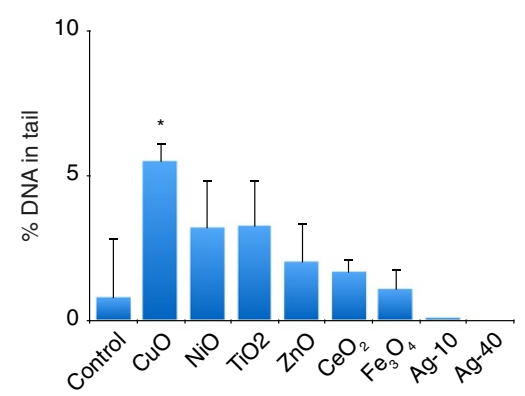

C
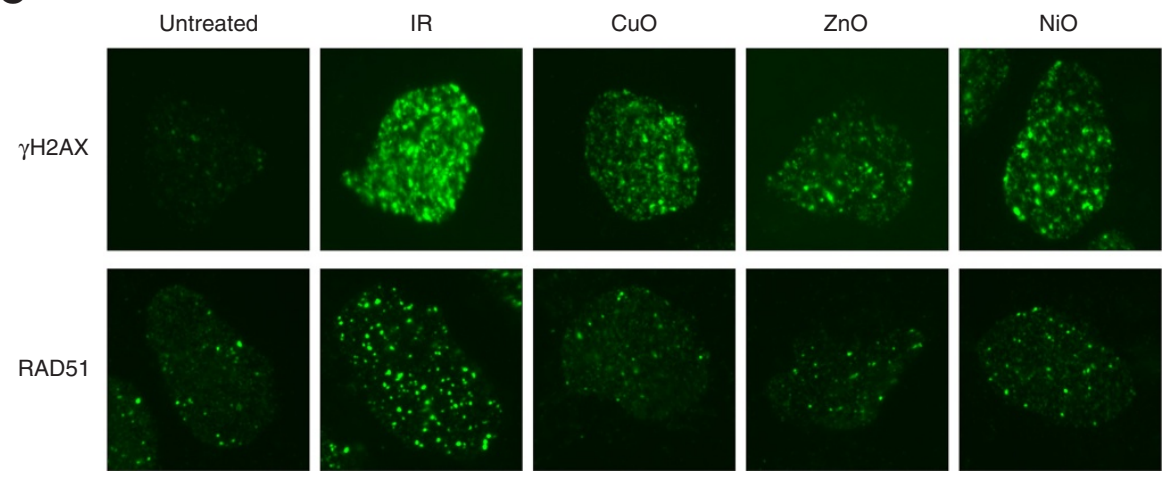

Figure 3 Conventional DNA damage assays confirm the ToxTracker response. (A) Induction of DNA strand breaks by the metal oxide NPs was determined by the comet assay under alkaline conditions. Wild type mES cells were exposed to NPs ( $20 \mu \mathrm{g} / \mathrm{mL})$ for $4 \mathrm{~h}$. $\mathrm{H}_{2} \mathrm{O}_{2}(10 \mu \mathrm{M}$ for 10 min on ice) was used as positive control. DNA damage was quantified as percentage of DNA in the comet tail. Results are presented as mean \pm standerd deviation of 3 independent experiments. (B) Induction of oxidative DNA lesions was determined by FPG comet. Wild type mES cells were exposed to NPs $(20 \mu \mathrm{g} / \mathrm{mL})$ for $4 \mathrm{~h}$ and results are expressed as net FPG sites. (C) Induction of $\mathrm{YH}_{2} \mathrm{AX}$ and RAD51 foci after 4 or $8 \mathrm{~h}$ exposure of mES cells to $\mathrm{CuO}(20 \mu \mathrm{g} / \mathrm{mL}), \mathrm{ZnO}(30 \mu \mathrm{g} / \mathrm{mL})$ and $\mathrm{NiO}(100 \mu \mathrm{g} / \mathrm{mL})$ NPs as determined by immunocytochemistry. DSBs induction after $10 \mathrm{~Gy}$ IR was used as positive control. 
dsDNA breaks. ZnO only caused effects at doses that at later time points were highly cytotoxic.

\section{The toxicity of $\mathrm{CuO}$ is mediated via ions whereas that of} $\mathrm{NiO}$ is particle-mediated

Since the NPs that showed induction of the ToxTracker reporters $(\mathrm{CuO}, \mathrm{ZnO}$ and $\mathrm{NiO})$ dissolve to various extents in the cell culture medium, we investigated the ToxTracker response induced by dissolved metal ions from easily soluble metal salts at different concentrations. It should be noted that the metal dissolution from the oxide NPs occurs over time and that the cellular effect therefore is difficult to mimic. Furthermore, complexation between dissolved metal ions and cell medium components changes the metal speciation, reducing the free ion concentration with time. Dissolved $\mathrm{Cu}$ from $\mathrm{CuSO}_{4}$ (assuming 100\% free $\mathrm{Cu}$ ions) induced the Srxn1-GFP oxidative stress reporter at doses starting from $50 \mu \mathrm{M}$ (Figure 4A) without any effects on cell viability (Figure 4B). When compared with released concentrations of $\mathrm{Cu}$ from the $\mathrm{CuO}$ NPs $(20 \mu \mathrm{g} / \mathrm{L})$ after $0 \mathrm{~h}(8 \mu \mathrm{M})$ and $24 \mathrm{~h}(117 \mu \mathrm{M})$ it is evident that the dissolved $\mathrm{Cu}$ fraction from $\mathrm{CuO} N$ Ps after $24 \mathrm{~h}$ was sufficient to induce oxidative stress. In the case of dissolved $\mathrm{Zn}$ from $\mathrm{ZnSO}_{4}$

\section{- Bscl2-GFP $\quad$ Srxn1-GFP $\triangle$ Btg2-GFP}

A

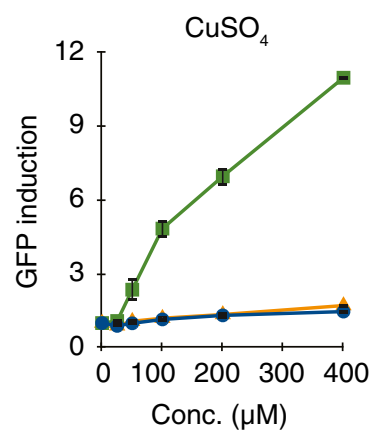

$\mathrm{ZnSO}_{4}$
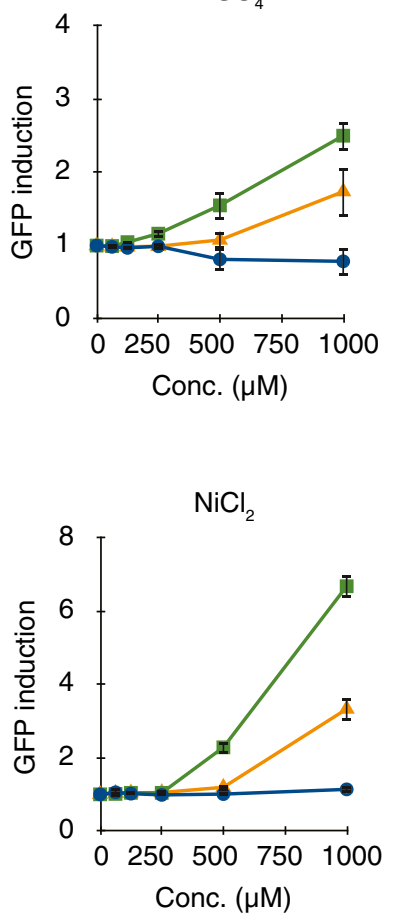

B
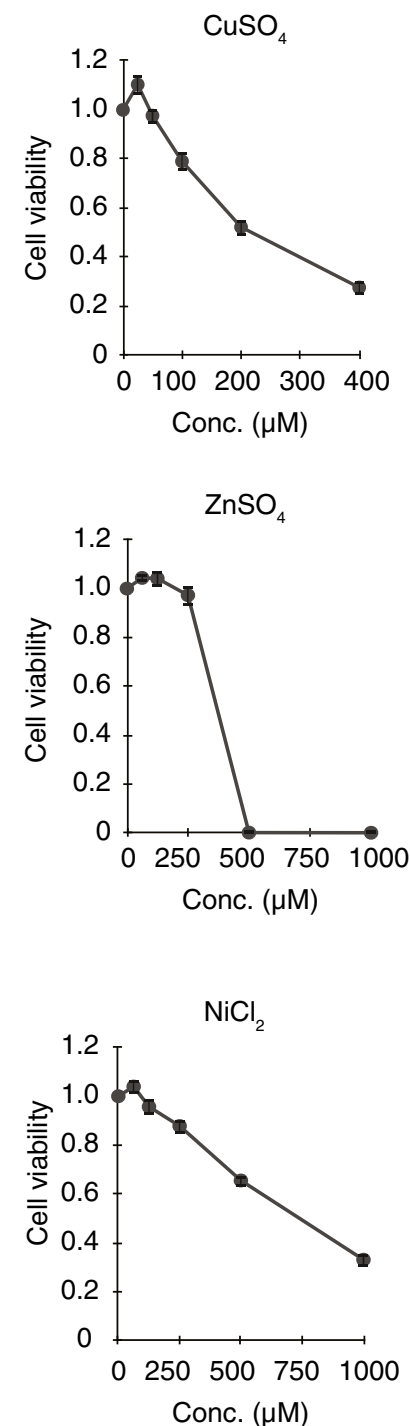

Figure 4 Induction of the ToxTracker assay by metal ions. mES cells were exposed to $\mathrm{CuSO}_{4}(25-1000 \mu \mathrm{M}), \mathrm{ZnSO}_{4}(50-1000 \mu \mathrm{M}), \mathrm{NiCl}_{2}$ $(50-1000 \mu \mathrm{M})$ for $24 \mathrm{~h}$. GFP induction and cell viability were determined with flow cytometry. Results are presented as mean \pm standard deviation of three independent experiments. 
(assuming 100\% free $\mathrm{Zn}$ ions), the Srxn1-GFP reporter response was mainly induced at concentrations exceeding $500 \mu \mathrm{M}$ and at these concentrations high cytotoxicity was observed making the ToxTracker results inconclusive (as for $\mathrm{ZnO} \mathrm{NPs}$ ). The particle effect was, however, pronounced for the NiO NPs compared to the response for dissolved $\mathrm{Ni}$ from $\mathrm{NiCl}_{2}$ (assuming $100 \%$ free $\mathrm{Ni}$ ions). For $\mathrm{NiCl}_{2}$, the ToxTracker Srxn1-GFP reporter was induced at concentrations $\geq 500 \mu \mathrm{M}$ and the Btg2-GFP reporter at concentrations of $1000 \mu \mathrm{M}$. Measured released concentrations from the NiO NPs after $24 \mathrm{~h}$ in cell medium were only minor $(17 \mu \mathrm{M})$ compared to these concentrations and could therefore not explain the observed toxicity. A comparison between the concentrations used for NPs $(\mathrm{CuO}, \mathrm{NiO}, \mathrm{ZnO})$ and their corresponding ions as well as the effect observed in ToxTracker is summarized in Table 2.

The ToxTracker assay responds to quartz particles but not to carbon-based materials

In order to benchmark the observed response to a particle control material we exposed the ToxTracker reporter cell lines to the carcinogenic quartz particles (DQ12). DQ12 is not a nanomaterial, but has often been used as a positive reactive particle control in both in vitro and in vivo studies on nanomaterials since it has high surface reactivity, inflammatory effects and induce oxidative DNA lesions at higher doses [24-26]. We also investigated whether the ToxTracker reporters were induced upon exposure to diesel particles (standard reference material SRM1650b) and carbon nanotubes (MWCNTs). Exposure to quartz particles clearly induced the Srxn1-GFP reporter at non-cytotoxic doses, starting from $50 \mu \mathrm{g} / \mathrm{mL}$ (Figure 5) supporting previous findings showing that ROS generation and more specifically hydroxyl radicals, play a major role for DQ12 induced genotoxicity [27]. On the other hand, no acellular ROS production was detected from the DQ12 particles (data not shown). In contrast, the MWCNTs and diesel particles did not induce the ToxTracker reporters. TEM images of mES cells exposed to MWCNTs indicated some uptake and there was also an increased side scatter shift analyzed by flow cytometry for both MWCNTs and diesel particles (Additional file 1:
Figure S2 and Additional file 1: Figure S3). Thus, lack of uptake is not a likely explanation for the lack of effect in the ToxTracker reporters. Diesel exhaust particles consist of a mixture of polycyclic aromatic hydrocarbons (PAH), transition metals and quinones adsorbed on a carbon core that can lead to genotoxicity mainly via PAH-DNA bulky adduct formation and partly by oxidative DNA damage $[28,29]$. Since PAHs require metabolic activation by cytochrome P450 enzymes in the liver and the lung before they become reactive, the effect of the diesel particles was also investigated in the presence of S9 rat liver extract. As a control for the activity of the S9 liver enzymes we treated the ToxTracker cells with the genotoxic compound aflatoxin B1 [16]. Treatment of mES cells with diesel particles in the presence of S9 did not lead to any reporter activation (Figure $5 \mathrm{~B}$ ). Thus, under the conditions tested in the present study, no pronounced genotoxicity/oxidative stress was observed for either the MWCNT or the diesel particles.

\section{Discussion}

The fast expansion of manufacturing and use of nanosized materials requires toxicity testing that should ideally be rapid, reliable, possible to use in a high-throughput manner and should provide information regarding the mechanisms of toxicity. These requirements are challenging to meet and will require development or implementation of novel tools. In this study we applied a novel fluorescence-based reporter assay for mechanism-based genotoxicity testing of various nanoparticles, in line with the $21^{\text {st }}$ century paradigm for nanomaterial testing which emphasizes the need for mechanism-based screening assays $[2,30]$. The ToxTracker reporter assay has previously been shown to discriminate between compounds that can directly interact with DNA causing stalled replication forks (that may ultimately lead to mutations and genome instability) and compounds that act via oxidative stress and subsequent oxidative DNA lesions. The mES cells that are used in the ToxTracker assay are untransformed, proficient in all major DNA damage and cellular stress response pathways and shown in this study to efficiently engulf nanoparticles. Exposure of the ToxTracker cells to $\mathrm{CuO}$ and $\mathrm{NiO}$ induced the Srxn-1 reporter but not the

Table 2 The ability of NPs and their corresponding metal ions to induce the ToxTracker reporters

\begin{tabular}{|c|c|c|c|c|c|c|}
\hline & $\mu \mathrm{g} / \mathrm{mL}$ & $\mu \mathrm{M}$ & $\mu \mathrm{g} \mathrm{metal} / \mathrm{mL}$ & ToxTracker induction & $\begin{array}{l}\mu \mathrm{g} \text { released metal } / \mathrm{mL} \\
\text { in cell medium }\end{array}$ & $\begin{array}{l}\text { Is the released metal in cell } \\
\text { medium likely to induce ToxTracker? }\end{array}$ \\
\hline CuO NPs & 20 & - & 15,8 & Yes & 7,4 & YES $\rightarrow$ ionic effect \\
\hline $\mathrm{CuSO}_{4}$ & - & 50 & 3,2 & Yes & - & \\
\hline NiO NPs & 20 & - & 15,6 & Yes & 1 & $\mathrm{NO} \rightarrow$ particle effect \\
\hline $\mathrm{NiCl}_{2}$ & - & 250 & 14,7 & No & - & \\
\hline ZnO NPs & 20 & - & 16,1 & Yes ( $\uparrow$ Tox) & 15,7 & Inconclusive due to high cytotoxicity \\
\hline $\mathrm{ZnSO}_{4}$ & - & 500 & 32,7 & Yes ( $\uparrow$ Tox) & - & \\
\hline
\end{tabular}




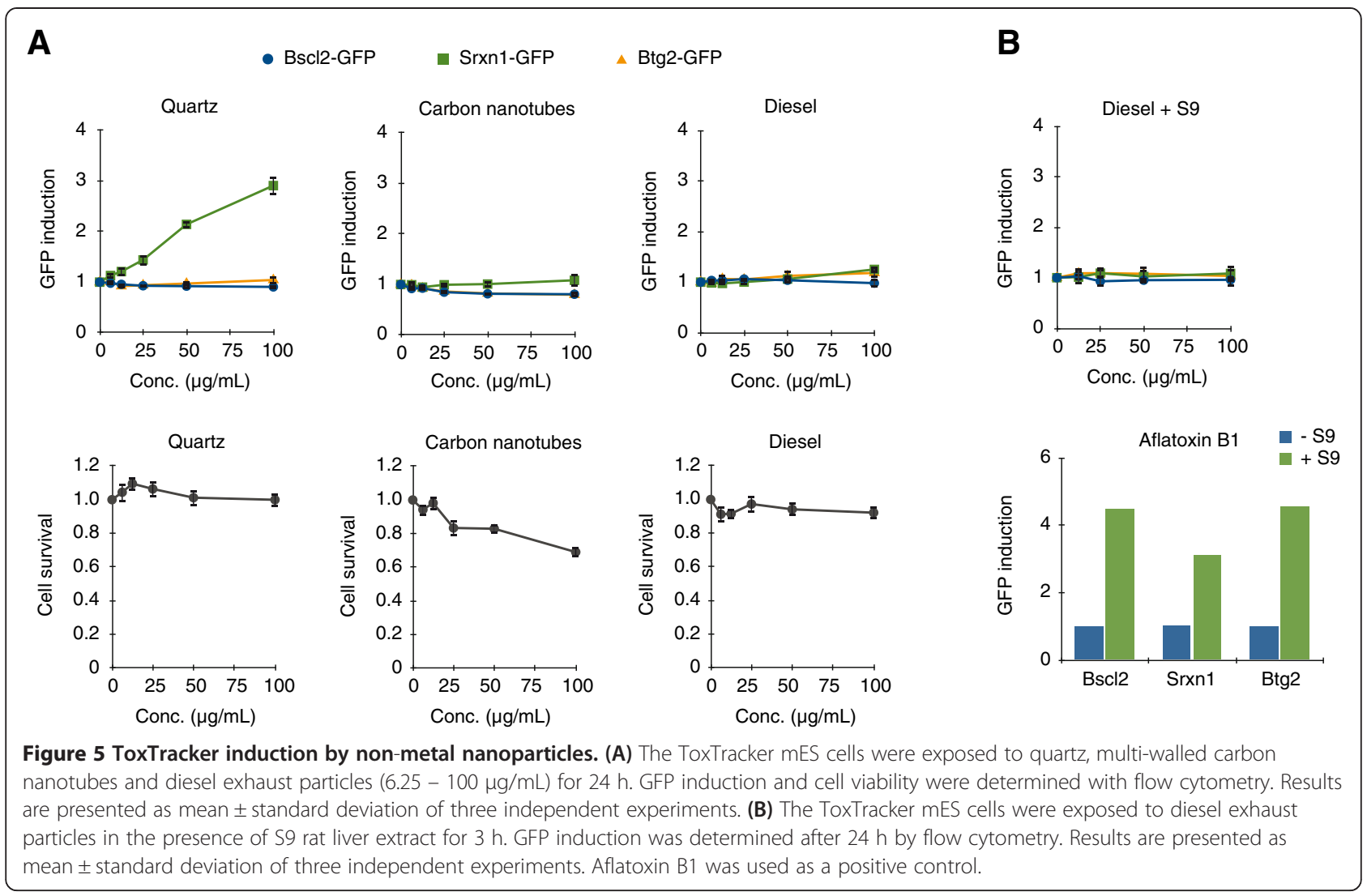

Bscl2 reporter (Figure 2), indicating that the main mechanism of toxicity is oxidative stress rather than direct DNA binding and subsequent interference with DNA replication. This is also in line with the positive response in the alkaline comet assay (detecting ssDNA breaks and alkaline labile sites), the positive FPG comets for $\mathrm{CuO}$, and the limited response in the neutral version of the assay as well as the lack of RAD51 foci formation (Figure 3). Identification of oxidative stress as primary mechanism of genotoxicity strongly decreases the carcinogenic hazard of these particles compared to agents that interact directly with DNA and interfere with DNA replication. The $\mathrm{TiO}_{2}$ NPs were positive in the comet assay but not in the ToxTracker. This might be explained by differences in sensitivity or possibly also that photocatalytic $\mathrm{TiO}_{2}$ NPs create additional strand breaks during the comet assay performance [12]. The Ag NPs included in the study showed no genotoxicity (comet assay and reporter cells) as well as no clear effect on the cell viability. Especially the lack of effects on cell viability after $24 \mathrm{~h}$ of the Ag-10 NPs was surprising considering the high cytotoxicity observed in BEAS-2B cells of these NPs [31].

In the present study, we carefully evaluated timedependent dissolution/metal ion release from the metal (oxide) nanoparticles in cell medium by means of ICPMS. In combination with experiments using soluble metal salts, we revealed that the effect observed for the $\mathrm{CuO}$ NPs could be explained by the released ions whereas the reporter activation (oxidative stress and p53 dependent stress) by $\mathrm{NiO}$ was related to the particles per se (Table 2). Indeed, our previous studies on lung epithelial cells suggested a high DNA damage potential of $\mathrm{CuO}$ and $\mathrm{NiO}$ NPs compared to other metal oxide NPs $[17,18]$ and the p53-dependent cellular stress response suggests additional reactivity of the $\mathrm{NiO}$ NPs compared to $\mathrm{CuO}$. The uptake of the $\mathrm{NiO}$ was high as assessed by the TEM images. Likely, intracellular release of $\mathrm{Ni}$ ions could be important for the reporter response, which would be in line with the Ni-ion bioavailability theory describing that the carcinogenicity of a Ni-compound depends on the cellular uptake and subsequent availability of $\mathrm{Ni}$ in the cell nucleus [32]. Nickel ions from particles can be transported to the nucleus [33] and have been suggested to interact with DNA in a manner that causes silencing of tumor suppressor genes, i.e. an epigenetic effect [34]. Thus, even though we did not observe any NPs in the nucleus, metal ions from the NPs may still be present in the nucleus and interact with DNA, but in a manner that does not cause replication stress according to our results.

In order to benchmark the observed responses in the reporter assay after metal NP exposure, we compared responses to the carcinogenic quartz material called 
DQ12 that have previously been shown to cause oxidative stress and inflammation in various test systems [24]. It is therefore often used as a positive insoluble particle control in nanotoxicology studies [25]. In line with earlier reporters, DQ12 showed a positive response in the oxidative stress reporter cell line observed already at sub-toxic doses (Figure 5). Furthermore, both $\mathrm{CuO}$ and (especially) $\mathrm{NiO}$ showed intrinsic ROS generating ability (as observed in the DCFH acellular ROS generating assay), but this was not observed for DQ12. This supports our previous work suggesting that cellular interaction/ lipid peroxidation is important for $\mathrm{SiO}_{2} \mathrm{NPs}$-induced toxicity [35]. $\mathrm{ZnO}$ did not produce acellular ROS and both $\mathrm{ZnO}$ and $\mathrm{ZnSO}_{4}$ only induced the oxidative stress reporter at highly cytotoxic doses (Figure 4B). This suggests that the reporter induction could be a secondary effect of the cytotoxicity in line with previous results that indicate that oxidative stress is not the primary cause of toxicity for $\mathrm{ZnO}[35,36]$.

MWCNTs and diesel particles did not induce the ToxTracker reporters suggesting lack of direct DNA interaction and comparatively low oxidative stress potential. Previous studies have also reported low ROS generation of these materials, although a slight increase in DNA damage has been observed for the MWCNTs [17] and an increase in the mutation frequency following repeated lung cell exposure to diesel particles [37]. The ToxTracker reporter cell lines were thus not activated following exposure to low-reactive carbon-based materials. ToxTracker response following exposure to carbon particles with higher reactivity, such as Printex 90 [37], requires further testing.

In this study, we show the applicability of the ToxTracker assay for rapid screening of genotoxic properties of NPs. Other approaches have also been suggested for this purpose. Recently, Li and co-workers [38] proposed that DNA-binding assays can be useful in this regard and showed that NPs (size range 3-46 nm) with a high affinity for DNA strongly inhibited DNA replication (tested acellularly), whereas NPs with low affinity had no or minimal effect. However, such experimental acellular studies do not consider important factors such as the ability of the NPs to enter the nucleus and the fact that DNA is highly packed in mammalian cells. The likelihood for nuclear localization and DNA interaction depends on the NP size as well as its charge. Nabiev et al. demonstrated that green $(2.1 \mathrm{~nm})$ quantum dots (QDs) but not red ones $(3.4 \mathrm{~nm})$ entered the nucleus of THP-1 cells via nuclear pore complexes [8] and Conroy et al. [39] furthermore showed that QDs preferentially bind to the positively charged core histone proteins as opposed to the DNA. Size-dependent effect has also been reported for gold NPs as those with a very specific size of $1.4 \mathrm{~nm}$ have been shown to interact in a unique manner with the major grooves of DNA, which was suggested to be the reason for the high toxicity of these NPs [40]. Interestingly, only marginally smaller or larger particles showed significantly reduced toxicity [41]. Some studies have reported direct interaction of NPs with DNA in bacterial cells [42-44]. Possibly, DNA binding may be a more relevant mechanism in bacterial cells where DNA is more "naked" (histone-free) in contrast to mammalian cells where DNA is packed in nucleosomes and chromosomes. DNA may still be more exposed during spontaneously conformational fluctuations, in which DNA transiently unwraps the histone core [45] or at transcriptionally active sites. At present, the general importance of such mechanisms for the genotoxicity of nanomaterials for mammalian cells remains unclear.

\section{Conclusions}

In this study, we have shown that the ToxTracker mES reporter cell assay can be applied as a rapid mechanismbased tool for assessing genotoxic effects of NPs. The assay is adapted to a 96-well plate format thus enabling medium/high throughput screening. $\mathrm{CuO}$ and $\mathrm{NiO}$ NPs caused a substantial reporter cell response that was related to oxidative stress rather than to direct interaction with DNA and stalled replication forks. $\mathrm{NiO}$ also induced the p53 dependent cellular stress reporter suggesting additional reactivity compared to $\mathrm{CuO}$. Furthermore, the reporter cell induction appeared to be mediated by dissolved metal ions from $\mathrm{CuO}$ whereas the responses observed from $\mathrm{NiO}$ were related to the particles per se. The assay was validated for metal oxide NPs whereas the applicability for carbon based nanomaterials needs to be further investigated. Obtained results indicate that the ToxTracker reporter system can be used as a rapid mechanism-based tool for assessing genotoxicity of metal oxide NPs.

\section{Materials and methods}

\section{Nanomaterials and soluble metal salts}

Nanoparticles of $\mathrm{CuO}(20-40 \mathrm{~nm}), \mathrm{ZnO}(20-200 \mathrm{~nm})$, $\mathrm{NiO}(2-70 \mathrm{~nm}), \mathrm{CeO}_{2}(4-30 \mathrm{~nm}), \mathrm{Fe}_{3} \mathrm{O}_{4}(20-40 \mathrm{~nm})$ and $\mathrm{TiO}_{2}(20-100 \mathrm{~nm}$, mix of rutile and anatase) as well as multi-walled carbon nanotubes (MWCNTs, 100-200 nm in diameter and 3-7 $\mu \mathrm{m}$ in length) were obtained from Sigma Aldrich. TEM images of these particles have been provided in previous studies $[17,18]$. Citrate coated Ag NPs (10 and $40 \mathrm{~nm}, 1 \mathrm{mg} / \mathrm{mL}$ dispersion in aqueous $2 \mathrm{mM}$ sodium citrate) were purchased from NanoComposix, Inc (San Diego, CA), diesel exhaust particles (powder, SRM 1650b) were obtained from National Institute of Standards and Technology (Gaithersburg, MD, USA) and quartz particles (crystalline silica DQ12) were a kind gift from Prof. Roel Schins, Leibniz Research Institute for Environmental Medicine, Düsseldorf, Germany. Soluble metal 
salts of $\mathrm{CuSO}_{4}, \mathrm{ZnSO}_{4}$ and $\mathrm{NiCl}_{2}$ were purchased from Sigma Aldrich.

\section{Hydrodynamic particle size in cell medium}

The size distribution in cell medium was investigated using dynamic light scattering (DLS) on an instrument employing photon cross correlation spectroscopy (PCCS) (NanoPhox, Sympatec, Germany). $20 \mu \mathrm{g} / \mathrm{mL}$ dispersions were prepared and analyzed directly after preparation. Single samples were measured three times at $25^{\circ} \mathrm{C}$. Data from the unique measurements was integrated to produce a single distribution with the PCCS software. Standard latex samples $(20 \pm 2 \mathrm{~nm})$ and blank samples were tested prior to analysis to ensure the accuracy of the measurements. The cell medium components resulted in a background contribution that was subtracted from the measured distribution for all nanomaterials investigated.

\section{Metal release in cell medium and cellular uptake of $\mathrm{CuO}$} The amount of released metals in $\mathrm{mES}$ cell culture medium was determined by inductively coupled plasma optical emission spectroscopy, ICP-OES (Thermo Scientific iCAP 6500 duo). $20 \mu \mathrm{g} / \mathrm{mL}$ dispersions of $\mathrm{CuO}, \mathrm{ZnO}$, $\mathrm{NiO}, \mathrm{TiO}_{2}, \mathrm{CeO}_{2}, \mathrm{Fe}_{3} \mathrm{O}_{4}$ NPs and of Ag-10 and Ag-40 NPs were prepared in complete cell culture medium. Metal release investigations were performed immediately after dispersion preparation $(0 \mathrm{~h})$ or kept at $37^{\circ} \mathrm{C}$ for $24 \mathrm{~h}$ after particle separation using a two-fold centrifugation procedure $\left(30 \mathrm{~min}, 13000 \mathrm{rpm}, 0^{\circ} \mathrm{C}\right)$. Successful particle separation was ensured using PCCS measurements. Total concentrations (limits of detection (LOD) in parenthesis) of $\mathrm{Cu}(0.3 \mu \mathrm{g} / \mathrm{L}), \mathrm{Zn}(0.1 \mu \mathrm{g} / \mathrm{L}), \mathrm{Ni}(0.4 \mu \mathrm{g} / \mathrm{L})$, Ce $(5 \mu \mathrm{g} / \mathrm{L})$, Fe $(0.3 \mu \mathrm{g} / \mathrm{L}), \mathrm{Ti}(0.1 \mu \mathrm{g} / \mathrm{L})$ and $\mathrm{Ag}(0.4 \mu \mathrm{g} / \mathrm{L})$ in solution were analyzed using standard operational procedures with multiple standards for calibration $(0,100,1000 \mu \mathrm{g} / \mathrm{L})$ and triplicate measurements of each sample. Parallel measurements were performed on selected elements ( $\mathrm{Ag}, \mathrm{Ti}, \mathrm{Zn}$ ) for quality control using atomic absorption spectroscopygraphite furnace, AAS-GF, (Perkin-Elmer Analyst 800). Mean metal concentrations of each element in solution are based on three replicate readings of each sample, independent of analytical method. Quality control samples were analyzed continuously throughout all analysis. All results are expressed as the released metal mass fraction of the total amount of exposed particles. The cellular uptake of $\mathrm{CuO}$ NPs was analyzed using AAS-GF as previously described [21].

\section{Acellular ROS generation}

To measure acelullar ROS production, the 2',7'-dichlorofluorescein diacetate (DCFH-DA) assay was used. In brief, sodium hydroxide $(0.01 \mathrm{M})$ was added to DCFHDA to cleave the DA from the DCFH. The reaction was stopped by the addition of HBSS (Hank's buffered salt solution). This solution was then incubated with the NPs in final concentrations of 10 and $50 \mu \mathrm{g} / \mathrm{mL}$ of NPs and $15 \mu \mathrm{M} \mathrm{DCFH}$ in $37^{\circ} \mathrm{C}$ for $30 \mathrm{~min}$. Fluorescence was recorded every 5 min over 30 min (excitation $485 \mathrm{~nm}$, emission $535 \mathrm{~nm}$ ) using a plate reader (Tecan Infinite F200) at $37^{\circ} \mathrm{C}$ and ROS generation was calculated as mean slope per min and normalized to the blank. ROS generation was considered increased when the value was 1.5 or above.

\section{Preparation of nanoparticle dispersions}

All powder particles were dispersed in cold $\mathrm{mES}$ culture medium by two times $10 \mathrm{~min}$ sonication at maximum power on ice (Bioruptor, Diagenode). The NP dispersions were diluted in warm BRL-conditioned mES culture medium, vortexed thoroughly and immediately added to the ToxTracker reporter cells. The Ag NPs were diluted directly in warm BRL-conditioned $\mathrm{mES}$ culture medium. NP dispersions were freshly prepared prior to exposure.

\section{mES cell culture and treatments}

Culture of the ToxTracker mES cells was performed as described previously [16]. The mES cells were maintained in the presence of irradiated mouse embryonic fibroblasts as feeder cells in Knockout DMEM containing 10\% fetal bovine serum, $2 \mathrm{mM}$ GlutaMAX, $1 \mathrm{mM}$ sodium pyruvate, $100 \mu \mathrm{M} \beta$-mercaptoethanol, and leukemia inhibitory factor (LIF). For NP analysis, cells were seeded $24 \mathrm{~h}$ prior to exposure on gelatin-coated plates using buffalo rat liver cell (BRL)-conditioned $\mathrm{mES}$ cell medium in the absence of feeder cells. Cells were continuously exposed for $24 \mathrm{~h}$ before GFP reporter analysis. The tested NP concentrations are based on cytotoxicity in mES cells after $24 \mathrm{~h}$ continuous exposure to a maximum test concentration at 50-75\% cytotoxicity. In case of no observed cytotoxicity, a top concentration of $50 \mathrm{or} 100 \mu \mathrm{g} / \mathrm{mL}$ was used. For analysis of diesel exhaust particles and compounds that require metabolic activation, cells were exposed for $3 \mathrm{~h}$ in the presence of $1 \% \mathrm{~S} 9$ rat liver extract in $3.2 \mathrm{mM} \mathrm{KCl}$, $0.8 \mathrm{mM} \mathrm{MgCl} 2,0.5 \mathrm{mM}$ glucose-6-phosphate and $0.4 \mathrm{mM}$ NADP. After $3 \mathrm{~h}$, the cells were washed with PBS and cultured for $24 \mathrm{~h}$ in BRL-conditioned medium without any nanomaterials.

\section{Cellular uptake and localization by TEM}

For TEM analysis, wild type B4418 $\mathrm{mES}$ cells were exposed to $20 \mu \mathrm{g} / \mathrm{mL} \mathrm{CuO}, 30 \mu \mathrm{g} / \mathrm{mL} \mathrm{ZnO}, 100 \mu \mathrm{g} / \mathrm{mL} \mathrm{NiO}$, $100 \mu \mathrm{g} / \mathrm{mL} \mathrm{CeO}{ }_{2}$ NPs, $10 \mu \mathrm{g} / \mathrm{mL} \mathrm{Ag-10}$ and $20 \mu \mathrm{g} / \mathrm{mL}$ MWCNT for $24 \mathrm{~h}$ and subsequently fixed in $4 \%$ glutaraldehyde, rinsed in phosphate buffer (PB) and centrifuged. The pellets were then post fixed in $2 \%$ osmium tetroxide in $0.1 \mathrm{M} \mathrm{PB}, \mathrm{pH} 7.4$ at $4^{\circ} \mathrm{C}$ for $2 \mathrm{~h}$, dehydrated in ethanol followed by acetone, and embedded in LX-112 (Ladd, Burlington, Vermont, USA). Ultrathin sections (approx. 60-80 $\mathrm{nm}$ ) were cut by a Leica ultracut UCT (Leica, 
Wien, Austria) and contrasted with uranyl acetate followed by lead citrate and examined with in Tecnai 12 Spirit Bio TWIN transmission electron microscope (Fei company, Eindhoven, The Netherlands) at $100 \mathrm{kV}$. Digital images were captured by using a Veleta camera (Olympus Soft Imaging Solutions, GmbH, Münster, Germany).

\section{The ToxTracker assay}

Bscl2-GFP, Srxn1-GFP and Btg2-GFP mES reporter cell lines were seeded in gelatin-coated 96-wells plates and exposed to various concentrations of NPs as described above. Induction of the GFP reporters was measured after $24 \mathrm{~h}$ continuous exposure using a 96-well Guava flow cytometer (Millipore) as described previously [16]. Simultaneously, cytotoxicity of the NPs was determined by measuring the concentration of intact cells after exposure using flow cytometry. All presented figures show the average GFP induction of at least three independent experiments. Error bars represent the standard error of the mean. The ToxTracker assay is considered positive above 1.5 fold increase in GFP signals. This limit is statistically based on 5 times the standard deviation of untreated controls and has been extensively validated in previous studies [16]. GFP induction levels at exposure concentration that induce $>75 \%$ cytotoxicity after $24 \mathrm{~h}$ exposure are discarded for ToxTracker analysis.

\section{Alkaline and FPG Comet Assay}

The mES cells were exposed to $20 \mu \mathrm{g} / \mathrm{mL}$ of nanoparticles for $4 \mathrm{~h}$. The alkaline and FPG version of the comet assay was then performed as previously described [17] with some modifications. In short, cells were embedded in agarose and lysed for $1 \mathrm{~h}$. For alkaline comet assay, alkaline unwinding and electrophoresis $(29 \mathrm{~V}, 1.15 \mathrm{~V} / \mathrm{cm})$ was then performed for 40 and $30 \mathrm{~min}$, respectively. For analysis of FPG-sensitive sites, following lysis cells were immersed $(3 \times 5 \mathrm{~min})$ in FPG enzyme buffer and $30 \mu \mathrm{L}$ of diluted (1:2500) FPG enzyme (kindly provided by Professor A. R. Collins, Department of Nutrition, School of Medicine, University of Oslo, Norway), or enzyme buffer, was added to each gel. Parafilm was placed on the slides, and incubation was performed in a humidity chamber at $37^{\circ} \mathrm{C}$ for $35 \mathrm{~min}$. DNA unwinding and electrophoresis $(1.15 \mathrm{~V} / \mathrm{cm})$ were then carried out for 30 and $20 \mathrm{~min}$, respectively. The comets were examined on a fluorescence microscope (Leica DMLB and Leica Axioplan2, Houston, TX) with Comet Assay IV (Perceptive Instruments) and CometScore (TriTek). software. For each sample, 50 comets were evaluated in each experiment. The level of FPG-sites was obtained by subtracting the value of $\%$ tail obtained with no enzyme added from the value when FPG-enzyme was present.

\section{Immunocytochemistry}

For detection of the DNA damage response after exposure to NPs, wild type B4418 mES cells were seeded on fibronectin-coated glass cover slips in BRL-conditioned $\mathrm{mES}$ cell medium. Cells were continuously exposed to $20 \mu \mathrm{g} / \mathrm{mL} \mathrm{CuO}, 30 \mu \mathrm{g} / \mathrm{mL} \mathrm{ZnO}, 100 \mu \mathrm{g} / \mathrm{mL} \mathrm{NiO}$ NPs or to $10 \mathrm{~Gy}$ ionizing radiation as positive control. After 4 or $8 \mathrm{~h}$, cells were fixed in 3\% paraformaldehyde and stained for $\mathrm{\gamma H}_{2} \mathrm{AX}$ or RAD51 as described previously [46]. RAD51 antibodies were a kind gift from Prof. R. Kanaar, rabbit anti- $\gamma \mathrm{H}_{2} \mathrm{AX}$ and alexa488-labeled secondary antibodies were purchased from Millipore and Invitrogen, respectively. Images were taken with a Zeiss Axioplan2 microscope equipped with a Zeiss Axiocam MRm camera using either a Plan-NEOFLUAR 40x/1.30 or a $63 x / 1.25$ objective.

\section{Additional file}

Additional file 1: Supporting information.

\section{Abbreviations}

AAS-GF: Atomic absorption spectroscopy-graphite furnace; ALS: Alkaline labile sites; ATR: Ataxia telangiectasia mutated and Rad3-related; AgNPs: Silver nanoparticles; DCFH-DA: Dichlorodihydrofluorescein diacetate; DLS: Dynamic light scattering; DSB: Double strand DNA breaks;

FPG: Formamidopyrimidine DNA glycosylase; GFP: Green fluorescent protein; HBSS: Hank's buffered salt solution; ICP-OES: Inductively coupled plasma optical emission spectroscopy; IR: lonizing radiation; mES: Mouse embryonic stem cells; MWCNTs: Multi-walled carbon nanotubes; Nrf2: Nuclear factor erythroid 2-related factor 2; PAH: Polycyclic aromatic hydrocarbons; PCCS: Photon cross correlation spectroscopy; ROS: Reactive oxygen species; TEM: Transmission electron microscopy; QDs: Quantum dots.

\section{Competing interests}

The authors declare that they have no competing interests.

\section{Authors' contribution}

HLK initiated and planned the study together with GH, performed some of the experiments including alkaline and FPG comet assay, was involved in data interpretation and wrote the final version of the manuscript. ARG participated in the design of the study, carried out part of the cellular work, prepared samples for the particle characterization, was involved in data interpretation and drafted the manuscript. FC and CG carried out part of the cellular work including alkaline and neutral comet assay. IOW supervised the particle characterization, metal dissolution and ICP-OES analyses and their interpretations and was involved in manuscript writing. BF and $\mathrm{HV}$ were involved in data interpretation and in manuscript writing. GH initiated and planned the study together with HLK, performed most of the cellular work and wrote a first draft of the manuscript. All authors have given approval to the final version of the manuscript.

\section{Acknowledgments}

This work was financially supported by the Netherlands Genomics Initiative/ Netherlands Organization for Scientific Research (NWO, project 050-060-510) The Swedish Research Council for Health, Working Life and Welfare (FORTE, project 2011-0832) and the European Commission (FP7-NanoREG, grant agreement no. 310584). ARG was supported by a Faculty Grant for PhD students (KID grant) from Karolinska Institutet. We thank S. Skoglund and G. Herting, KTH for help with the PCCS and ICP-AES analysis, respectively, K. Hultenby, KI for TEM imaging, colleagues at the department of Toxicogenetics in the LUMC for support, Prof. Roel Schins for providing the DQ12 particles and Prof. R. Kanaar for the RAD51 antibodies. 


\section{Author details}

${ }^{1}$ Nanosafety \& Nanomedicine Laboratory, Division of Molecular Toxicology, Institute of Environmental Medicine, Karolinska Institutet, Stockholm, Sweden. ${ }^{2}$ Department of Toxicogenetics, Leiden University Medical Center, Leiden, the Netherlands. ${ }^{3} \mathrm{KTH}$ Royal Institute of Technology, Division of Surface and Corrosion Science, School of Chemical Science and Engineering, Stockholm, Sweden.

Received: 13 March 2014 Accepted: 12 August 2014

Published: 2 September 2014

\section{References}

1. Fadeel B, Feliu N, Vogt C, Abdelmonem AM, Parak WJ: Bridge over troubled waters: understanding the synthetic and biological identities of engineered nanomaterials. Wiley Interdiscip Rev Nanomed Nanobiotechnol 2013, 5(2):111-129.

2. Nel AE, Nasser $E_{,}$Godwin $H$, Avery $D$, Bahadori T, Bergeson L, Beryt $E$, Bonner JC, Boverhof D, Carter J, Castranova V, Deshazo JR, Hussain SM, Kane AB, Klaessig F, Kuempel E, Lafranconi M, Landsiedel R, Malloy T, Miller MB, Morris J, Moss K, Oberdorster G, Pinkerton K, Pleus RC, Shatkin JA, Thomas R, Tolaymat T, Wang A, Wong J: A multi-stakeholder perspective on the use of alternative test strategies for nanomaterial safety assessment. ACS Nano 2013, 7:6422-6433.

3. Xia T, Kovochich M, Brant J, Hotze M, Sempf J, Oberley T, Sioutas C, Yeh Jl, Wiesner MR, Nel AE: Comparison of the abilities of ambient and manufactured nanoparticles to induce cellular toxicity according to an oxidative stress paradigm. Nano Lett 2006, 6(8):1794-1807.

4. Cho WS, Duffin R, Poland CA, Duschl A, Oostingh GJ, Macnee W, Bradley M, Megson IL, Donaldson K: Differential pro-inflammatory effects of metal oxide nanoparticles and their soluble ions in vitro and in vivo; zinc and copper nanoparticles, but not their ions, recruit eosinophils to the lungs. Nanotoxicology 2012, 6(1):22-35.

5. Xia T, Kovochich M, Liong M, Mädler L, Gilbert B, Shi H, Yeh Jl, Zink Jl, Nel AE: Comparison of the Mechanism of Toxicity of Zinc Oxide and Cerium Oxide Nanoparticles Based on Dissolution and Oxidative Stress Properties. ACS Nano 2008, 2(10):2121-2134.

6. Magdolenova Z, Collins A, Kumar A, Dhawan A, Stone V, Dusinska M: Mechanisms of genotoxicity. A review of in vitro and in vivo studies with engineered nanoparticles. Nanotoxicology 2013, 20:20.

7. Singh N, Manshian B, Jenkins GJ, Griffiths SM, Williams PM, Maffeis TG, Wright CJ, Doak SH: NanoGenotoxicology: the DNA damaging potential of engineered nanomaterials. Biomaterials 2009, 30(23-24):3891-3914.

8. Nabiev I, Mitchell S, Davies A, Williams Y, Kelleher D, Moore R, Gun'ko YK, Byrne S, Rakovich YP, Donegan JF, Sukhanova A, Conroy J, Cottell D, Gaponik N, Rogach A, Volkov Y: Nonfunctionalized nanocrystals can exploit a cell's active transport machinery delivering them to specific nuclear and cytoplasmic compartments. Nano Lett 2007, 7:3452-3461.

9. Kim HR, Kim MJ, Lee SY, Oh SM, Chung KH: Genotoxic effects of silve nanoparticles stimulated by oxidative stress in human normal bronchial epithelial (BEAS-2B) cells. Mutat Res 2011, 726(2):129-135.

10. Chen $M$, Von Mikecz A: Formation of nucleoplasmic protein aggregates impairs nuclear function in response to $\mathrm{SiO} 2$ nanoparticles. Exp Cell Res 2005, 305(1):51-62.

11. Wang Z, Li N, Zhao J, White JC, Qu P, Xing B: CuO nanoparticle interaction with human epithelial cells: cellular uptake, location, export, and genotoxicity. Chem Res Toxicol 2012, 25(7):1512-1521.

12. Karlsson HL: The comet assay in nanotoxicology research. Anal Bioanal Chem 2010, 398(2):651-666

13. Prasad RY, McGee JK, Killius MG, Suarez DA, Blackman CF, DeMarini DM, Simmons SO: Investigating oxidative stress and inflammatory responses elicited by silver nanoparticles using high-throughput reporter genes in HepG2 cells: effect of size, surface coating, and intracellular uptake. Toxicol In Vitro 2013, 27(6):2013-2021.

14. Hastwell PW, Chai LL, Roberts KJ, Webster TW, Harvey JS, Rees RW, Walmsley RM: High-specificity and high-sensitivity genotoxicity assessment in a human cell line: validation of the GreenScreen $\mathrm{HC}$ GADD45a-GFP genotoxicity assay. Mutat Res 2006, 607(2):160-175.

15. Hendriks G, van de Water B, Schoonen W, Vrieling H: Cellular-signaling pathways unveil the carcinogenic potential of chemicals. J Appl Toxicol 2013, 33(6):399-409.
16. Hendriks G, Atallah M, Morolli B, Calleja F, Ras-Verloop N, Huijskens I, Raamsman M, van de Water B, Vrieling H: The ToxTracker assay: novel GFP reporter systems that provide mechanistic insight into the genotoxic properties of chemicals. Toxicol Sci 2012, 125(1):285-298.

17. Karlsson HL, Cronholm P, Gustafsson J, Moller L: Copper oxide nanoparticles are highly toxic: a comparison between metal oxide nanoparticles and carbon nanotubes. Chem Res Toxicol 2008, 21(9):1726-1732.

18. Kain J, Karlsson HL, Moller L: DNA damage induced by micro- and nanoparticles-interaction with FPG influences the detection of DNA oxidation in the comet assay. Mutagenesis 2012, 27(4):491-500.

19. Bhabra G, Sood A, Fisher B, Cartwright L, Saunders M, Evans WH, Surprenant A, Lopez-Castejon G, Mann S, Davis SA, Hails LA, Ingham E, Verkade P, Lane J, Heesom K, Newson R, Case CP: Nanoparticles can cause DNA damage across a cellular barrier. Nat Nanotechnol 2009, 4:876-883.

20. Doak SH, Manshian B, Jenkins GJ, Singh N: In vitro genotoxicity testing strategy for nanomaterials and the adaptation of current $O E C D$ guidelines. Mutat Res 2012, 745(1-2):104-111.

21. Cronholm P, Karlsson HL, Hedberg J, Lowe TA, Winnberg L, Elihn K, Wallinder IO, Moller L: Intracellular uptake and toxicity of $\mathrm{Ag}$ and $\mathrm{CuO}$ nanoparticles: a comparison between nanoparticles and their corresponding metal ions. Small 2013, 9(7):970-82. doi:10.1002/ smll.201201069. Epub 2013 Jan 7.

22. Banath JP, Banuelos CA, Klokov D, MacPhail SM, Lansdorp PM, Olive PL: Explanation for excessive DNA single-strand breaks and endogenous repair foci in pluripotent mouse embryonic stem cells. Exp Cell Res 2009, 315(8):1505-1520.

23. Daboussi F, Dumay A, Delacote F, Lopez BS: DNA double-strand break repair signalling: the case of RAD51 post-translational regulation. Cell Signal 2002, 14(12):969-975.

24. Duffin R, Tran L, Brown D, Stone V, Donaldson K: Proinflammogenic effects of low-toxicity and metal nanoparticles in vivo and in vitro: highlighting the role of particle surface area and surface reactivity. Inhal Toxicol 2007, 19(10):849-856.

25. Klein CL, Wiench K, Wiemann M, Ma-Hock L, Van Ravenzwaay B, Landsiede R: Hazard identification of inhaled nanomaterials: making use of shortterm inhalation studies. Arch Toxicol 2012, 86(7):1137-1151.

26. Van Berlo D, Wessels A, Boots AW, Wilhelmi V, Scherbart AM, Gerloff K, Van Schooten FJ, Albrecht C, Schins RP: Neutrophil-derived ROS contribute to oxidative DNA damage induction by quartz particles. Free Radic Biol Med 2010, 49(11):1685-1693.

27. Schins RP, Knaapen AM, Cakmak GD, Shi T, Weishaupt C, Borm PJ: Oxidantinduced DNA damage by quartz in alveolar epithelial cells. Mutat Res 2002, 517(1-2):77-86.

28. Dybdahl M, Risom L, Bornholdt J, Autrup H, Loft S, Wallin H: Inflammatory and genotoxic effects of diesel particles in vitro and in vivo. Mutat Res 2004, 562(1-2):119-131.

29. Wichmann HE: Diesel exhaust particles. Inhal Toxicol 2007, 1:241-244

30. Nel AE: Implementation of alternative test strategies for the safety assessment of engineered nanomaterials. J Intern Med 2013, 24(10):12109.

31. Gliga AR, Skoglund S, Wallinder IO, Fadeel B, Karlsson HL: Size-dependent cytotoxicity of silver nanoparticles in human lung cells: the role of cellular uptake, agglomeration and Ag release. Part Fibre Toxicol 2014, 11:11.

32. Goodman JE, Prueitt RL, Thakali S, Oller AR: The nickel ion bioavailability model of the carcinogenic potential of nickel-containing substances in the lung. Crit Rev Toxicol 2011, 41(2):142-174.

33. Ke Q, Davidson T, Kluz T, Oller A, Costa M: Fluorescent tracking of nickel ions in human cultured cells. Toxicol Appl Pharmacol 2007, 219(1):18-23.

34. Brocato J, Costa M: Basic mechanics of DNA methylation and the unique landscape of the DNA methylome in metal-induced carcinogenesis. Crit Rev Toxicol 2013, 43(6):493-514.

35. Shi J, Karlsson HL, Johansson K, Gogvadze V, Xiao L, Li J, Burks T, GarciaBennett A, Uheida A, Muhammed M, Mathur S, Morgenstern R, Kagan VE, Fadeel B: Microsomal glutathione transferase 1 protects against toxicity induced by silica nanoparticles but not by zinc oxide nanoparticles. ACS Nano 2012, 6:1925-1938.

36. Buerki-Thurnherr $\mathrm{T}$, Xiao L, Diener L, Arslan O, Hirsch C, Maeder-Althaus X, Grieder K, Wampfler B, Mathur S, Wick P, Krug HF: In vitro mechanistic study towards a better understanding of $\mathrm{ZnO}$ nanoparticle toxicity. Nanotoxicology 2013, 7:402-416. 
37. Jacobsen NR, Moller P, Cohn CA, Loft S, Vogel U, Wallin H: Diesel exhaust particles are mutagenic in FE1-MutaMouse lung epithelial cells. Mutat Res 2008, 641(1-2):54-57.

38. Li K, Zhao X, KH B, Du S, Chen Y: Nanoparticles inhibit DNA replication by binding to DNA: modeling and experimental validation. ACS Nano 2013, 7(11):9664-9674.

39. Conroy J, Byrne SJ, Gun'ko YK, Rakovich YP, Donegan JF, Davies A, Kelleher D, Volkov Y: CdTe nanoparticles display tropism to core histones and histone-rich cell organelles. Small 2008, 4(11):2006-2015.

40. Tsoli M, Kuhn H, Brandau W, Esche H, Schmid G: Cellular uptake and toxicity of Au55 clusters. Small 2005, 1(8-9):841-844.

41. Pan Y, Neuss S, Leifert A, Fischler M, Wen F, Simon U, Schmid G, Brandau W, Jahnen-Dechent W: Size-dependent cytotoxicity of gold nanoparticles. Small 2007, 3(11):1941-1949.

42. Giannousi K, Lafazanis K, Arvanitidis J, Pantazaki A, Dendrinou-Samara C: Hydrothermal synthesis of copper based nanoparticles: antimicrobial screening and interaction with DNA. J Inorg Biochem 2014, 133:24-32.

43. Grigor'eva A, Saranina I, Tikunova N, Safonov A, Timoshenko N, Rebrov A, Ryabchikova E: Fine mechanisms of the interaction of silver nanoparticles with the cells of Salmonella typhimurium and Staphylococcus aureus. Biometals 2013, 26(3):479-488.

44. An H, Liu Q, Ji Q, Jin B: DNA binding and aggregation by carbon nanoparticles. Biochem Biophys Res Commun 2010, 393(4):571-576.

45. Li G, Levitus M, Bustamante C, Widom J: Rapid spontaneous accessibility of nucleosomal DNA. Nat Struct Mol Biol 2005, 12(1):46-53.

46. Vrouwe MG, Pines A, Overmeer RM, Hanada K, Mullenders LH: UV-induced photolesions elicit ATR-kinase-dependent signaling in non-cycling cells through nucleotide excision repair-dependent and -independent pathways. J Cell Sci 2011, 124(Pt 3):435-446.

doi:10.1186/s12989-014-0041-9

Cite this article as: Karlsson et al:: Mechanism-based genotoxicity screening of metal oxide nanoparticles using the ToxTracker panel of reporter cell lines. Particle and Fibre Toxicology 2014 11:41.

\section{Submit your next manuscript to BioMed Central and take full advantage of:}

- Convenient online submission

- Thorough peer review

- No space constraints or color figure charges

- Immediate publication on acceptance

- Inclusion in PubMed, CAS, Scopus and Google Scholar

- Research which is freely available for redistribution 